\title{
Mitral valve replacement with Alvarez prosthesis: long-term results
}

\author{
Y. A. S. MASHHOUR, J.B. GARCIA, M. IONESCU, AND \\ G. H. WOOLER \\ From the General Infirmary, Leeds
}

\begin{abstract}
The high mortality and morbidity that follow insertion of the Alvarez valve in the mitral position, and particularly the thrombo-embolic complications, stopped us from using it clinically in the Leeds General Infirmary.
\end{abstract}

Since the introduction of the Alvarez mitral valve prosthesis in 1964 it has been used clinically in Leeds General Infirmary because it was thought that it would produce better haemodynamic results than the other prosthetic valves.

The aim of this study is to present the longterm results in patients who had this prosthesis inserted in the mitral valve position, and to show the high incidence of thrombo-embolic manifestations.

\section{CLINICAL MATERIAL}

Since 25 August 1964 the Alvarez prosthetic valve has been inserted in the mitral position in 29 patients. This group of totally unselected patients had a mixed mitral valve lesion. They were 17 women and 12 men aged between 11 and 52 years, average age 36 years. Some of these patients had associated aortic or tricuspid valvular disease (Table I). Two had aortic incompetence, which was thought to be mild when

T A B L E I

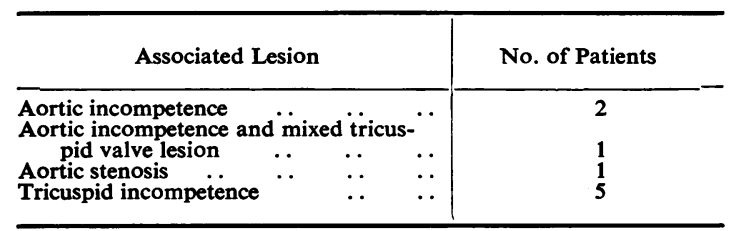

assessed pre-operatively and proved to be so during the operation because the aorta had not to be crossclamped. Another patient had associated aortic incompetence and a mixed tricuspid valve lesion, both of which were considered to be mild and did not require surgical treatment.

Five patients had associated tricuspid incompetence; in three it was considered to be functional and was left alone, but in two others repair of the tricuspid valve was performed at the time the mitral valve was replaced.

Associated aortic stenosis was found in only one patient; it was thought to be mild and was not treated, but the patient died one month after operation and necropsy revealed moderately severe aortic stenosis.

Seven patients had had previous operations on the mitral valve (Table II).

T A B L E I I

\begin{tabular}{|c|c|}
\hline Type of Previous Operation & No. of Patients \\
\hline $\begin{array}{l}\text { Mitral valve repair } \ldots \\
\text { Transventricular closed mitral valvotomy } \\
\text { Mitral valve exploration with finger } \\
\text { (not suitable to proceed with valvotomy) }\end{array}$ & $\begin{array}{l}1 \text {-one valvotomy } \\
1 \text {-two valvotomies } \\
2 \text {-two }\end{array}$ \\
\hline
\end{tabular}

Calcification was present in 19 of the 29 patients. All the 29 patients had severe disease of the chordae tendineae, so that none of the valves was suitable for repair.

The operative technique was the same in all patients, using the Melrose machine for extracorporeal circulation, combined with mild hypothermia to $33^{\circ}$ or $34^{\circ} \mathrm{C}$. The heart was fibrillated electrically on full perfusion. Tracheostomy at the end of the operation was performed only when necessary.

All the patients were anticoagulated on the fifth post-operative day.

\section{RESULTS}

Out of the 29 patients mentioned above, 14 are still alive. The time and cause of death of the 15 deceased patients is given in Tables III, IV, V, and VI respectively.

Considering Table VI, in patient 1 there is conclusive evidence that clotting occurred on the valve, necessitating re-operation to remove that 
T A B L E I I I

\begin{tabular}{|c|c|}
\hline Classification & No. of Patients \\
\hline $\begin{array}{l}\text { Operative death (within } 2 \text { weeks of operation) } \\
\text { Hospital death (from 2-6 weeks) } \\
\text { Late mortality (after } 6 \text { weeks) }\end{array}$ & $\begin{array}{l}8 \\
1 \\
6\end{array}$ \\
\hline
\end{tabular}

T A B LE IV

OPERATIVE MORTALITY

\begin{tabular}{|c|c|}
\hline Cause of Death & Post-mortem Examination of Relevance \\
\hline Pulmonary oedema .. & $\begin{array}{l}\text { Pulmonary oedema and pulmonary fat } \\
\text { embolism }\end{array}$ \\
\hline $\begin{array}{l}\text { Pulmonary oedema and } \\
\text { low cardiac output }\end{array}$ & Outflow tract obstruction demonstrated \\
\hline Acute cardiac failure & Lung congestion and liver infarct \\
\hline $\begin{array}{l}\text { Acute cardiac failure. } \\
\text { Brain damage }\end{array}$ & $\begin{array}{l}\text { Brain softening. Infarct of corpus callo- - } \\
\text { sum roof of the lateral ventricle on each } \\
\text { side; infarction of right cerebellar } \\
\text { hemisphere }\end{array}$ \\
\hline $\begin{array}{l}\text { Acute cardiac failure. } \\
\text { Brain damage }\end{array}$ & Cerebellar infarct \\
\hline Ventricular fibrillation & $\begin{array}{l}\text { Evidence of outflow tract obstruction, } \\
\text { lung congestion, hyperaemia right } \\
\text { parietal lobe }\end{array}$ \\
\hline $\begin{array}{l}\text { Cardiac arrest } \\
\text { (metabolic disturbance) }\end{array}$ & Nothing of any relevance \\
\hline $\begin{array}{l}\text { On table from uncon- } \\
\text { trollable haemorrhage }\end{array}$ & $\begin{array}{l}\text { Ruptured myocardium; the rigid vent } \\
\text { used to keep the valve incompetent per- } \\
\text { forated the very thin ventricular wall. }\end{array}$ \\
\hline
\end{tabular}

T A B L E V

HOSPITAL MORTALITY

\begin{tabular}{c|c}
\hline Cause of Death & Post-mortem Examination \\
\hline $\begin{array}{c}\text { Cardiac arrest 1 month after } \\
\text { operation }\end{array}$ & Moderately severe aortic stenosis \\
\hline
\end{tabular}

\section{T A B L E V I}

\section{LATE MORTALITY}

\begin{tabular}{|c|c|c|}
\hline Patient & Cause of Death & $\begin{array}{l}\text { Post-mortem Examina- } \\
\text { tion of Relevance }\end{array}$ \\
\hline 1 & $\begin{array}{l}\text { Cardiac arrest after re-operation } \\
\text { to extract clot from Alvarez pros- } \\
\text { thesis } 4 \text { months after inserion }\end{array}$ & $\begin{array}{l}\text { An old infarct in right } \\
\text { frontal lobe and left } \\
\text { insula }\end{array}$ \\
\hline 2 & $\begin{array}{l}\text { Cardiac failure } 1.5 \text { years post-op. } \\
\text { in hospital while being prepared } \\
\text { for second operation to replace } \\
\text { the Alvarez which became in- } \\
\text { competent. Patient developed } 2 \\
\text { attacks of cerebral embclism } \\
\rightarrow \text { right hemiplegia in hospital }\end{array}$ & Not done \\
\hline 3 & $\begin{array}{l}\text { Brain damage and secondary } \\
\text { haemorrhage }\end{array}$ & $\begin{array}{l}\text { Cerebral infarction } \\
\text { (anticoagulants stop- } \\
\text { ped because he de- } \\
\text { veloped torrential } \\
\text { haemorrhage from a } \\
\text { duodenal ulcer) }\end{array}$ \\
\hline $\begin{array}{l}4 \\
5 \\
6\end{array}$ & $\begin{array}{l}\text { Brain damage (embolism) } \\
\text { Died at home-not known } \\
\text { Died at home-not known }\end{array}$ & Not done \\
\hline
\end{tabular}

clot. In patient 2 , her condition was deteriorating due to the fact that she again developed mitral incompetence. This led to the development of right-sided heart failure and tricuspid incompetence. She was scheduled for open heart surgery to replace the Alvarez valve with a heterograft late in 1967. While she was in hospital on full anticoagulant therapy she had two separate cerebral emboli which produced a right hemiplegia. While awaiting recovery from her cerebral condition she developed cardiac failure which did not respond to medical treatment, and she passed into liver failure and death.

Patient 3 (Table VI) developed torrential haemorrhage from a duodenal ulcer and anticoagulants had to be stopped. Immediately afterwards he developed a cerebral embolus and died in hospital.

Patient 4 also died one year after operation from a cerebral embolus which produced a right hemiplegia.

Both patients 5 and 6 (Table VI) died suddenly at home, presumably due to cerebral emboli, because their hearts were good and indeed they were more or less symptomless before they died.

All patients were found to be grade IIB preoperatively when their exercise tolerance was assessed. Their exercise tolerance grading after operation is shown in Table VII.

\section{T A B L E V I I}

GRADING OF SURVIVORS ACCORDING TO EFFORT TOLERANCE (Before operation all were grade IIB)

\begin{tabular}{ccccc|c} 
Grade of Effort Tolerance after Operation & No. of Patients \\
\hline O & $\ldots$ & $\ldots$ & $\ldots$ & $\ldots$ & 2 \\
II & $\ldots$ & $\ldots$ & $\ldots$ & $\ldots$ & 5 \\
IIA & $\ldots$ & $\ldots$ & $\ldots$ & $\ldots$ & 6 \\
III & $\ldots$ & $\ldots$ & $\ldots$ & $\ldots$ & 1 \\
IV & $\ldots$ & $\ldots$ & $\ldots$ & $\ldots$ & 0 \\
\end{tabular}

Until the present time only six patients out of the 29 operated upon are free from thromboembolic manifestation.

COMPLICATIONS In the group of survivors a multitude of complications developed either immediately or late after the operation. Thromboembolism proved to be the commonest and the most important. The following other complications are mentioned in order of their occurrence after the time of the operation:

Low cardiac output

2 patients

Pulmonary oedema

1 patient

Post-perfusion syndrome

1 patient

Pleural effusion

2 patients 
Cardiac tamponade

1 patient

Chest infection

Bronchopneumonia

1 patient

Persistent bronchitis

1 patient

Heart failure

1 patient

Persistent auricular fibrillation

1 patient (in sinus rhythm pre-operatively)

Subacute bacterial endocarditis

2 patients

Serious anaemia

1 patient

Tracheal stenosis

1 patient

Thrombo-embolic manifestations

Early Late

1 patient (cerebral and renal)

7 patients (All were cerebral. One has a complete personality change which is persistent. The remaining six patients had more or less transient attacks of hemiplegia, hemiparesis, aphasia, homonymous hemianopia, etc.)

\section{DISCUSSION}

In this group of 29 patients who had replacement of the mitral valve with an Alvarez valve prosthesis, the total mortality rate was $51 \cdot 7 \%$.

Of the survivors $57.3 \%$ developed thromboembolic complications. There were no immediate cerebral lesions following surgery which could have been caused by air or calcium during the operation. It is right to assume that the last two patients mentioned in Table VI died from cerebral emboli, so the total percentage of thromboembolism in this series of patients operated upon is $62 \cdot 1 \%$.

Table VIII compares the thrombo-embolic rate of other prosthetic valves with that of the Alvarez.

\section{T A B LE V I I I}

\begin{tabular}{|c|c|c|c|}
\hline Type of Prosthesis & $\begin{array}{l}\text { No. of } \\
\text { Patients }\end{array}$ & $\begin{array}{l}\text { No. of } \\
\text { Thrombo-embolic } \\
\text { Complications }\end{array}$ & Percentage \\
\hline 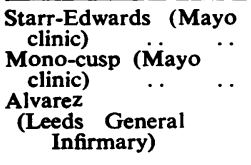 & $\begin{array}{r}166 \\
35 \\
29\end{array}$ & $\begin{array}{r}54 \\
6 \\
16\end{array}$ & $\begin{array}{l}32 \cdot 5 \\
17 \cdot 1 \\
62 \cdot 1\end{array}$ \\
\hline
\end{tabular}

The rate is very high for the Alvarez prosthesis and we believe that it is due to clot forming on the hinge joint mechanism (Figure). We therefore ceased to use this prosthesis after February 1967 because we were unable to prevent systemic emboli with full anticoagulant control.
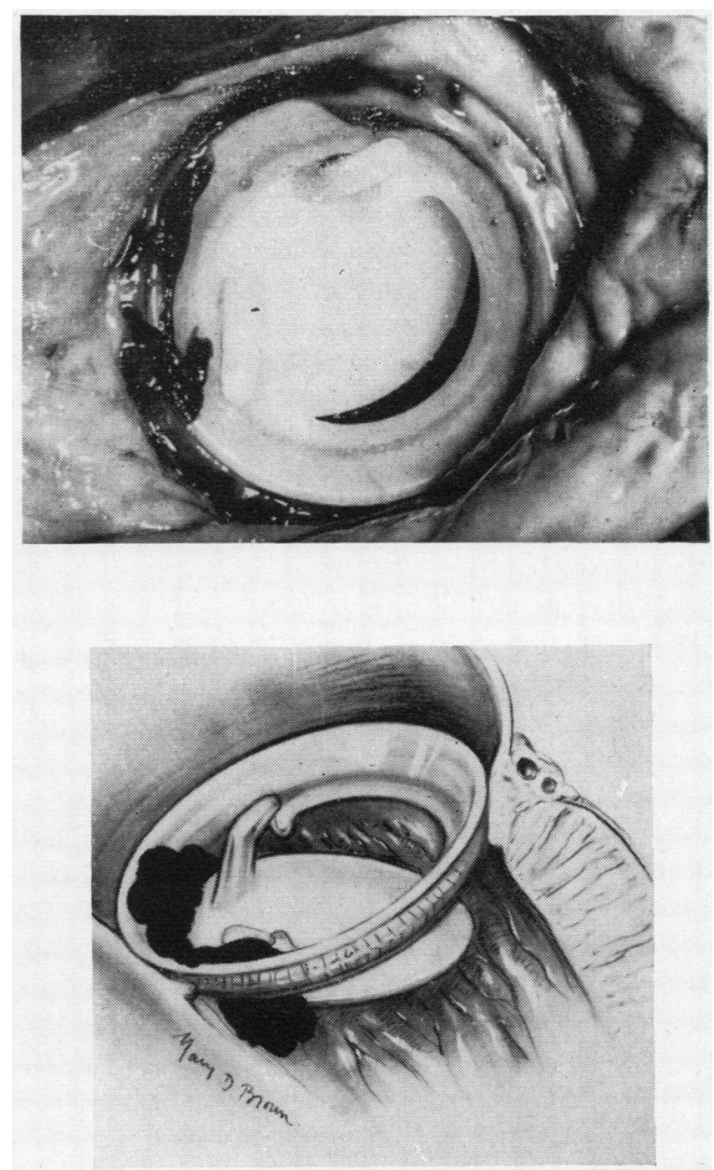

FIGURE Photograph and artist's sketch of clot forming over the Alvarez prosthetic valve.

Starr, Herr, and Wood (1967) report an embolic rate of $43 \%$ using the old type of mitral valve prosthesis on 597 patients from 1960 to 1965. However, from 1965 to 1967 , using the extended cloth prosthesis on 151 patients, only one embolus occurred. All patients have been maintained on anticoagulant therapy. Only recently have we commenced in Leeds to use the new extended cloth prosthesis. 
I should like to thank Miss Beryl Walsh for the photograph and Miss Mary Brown for the artist's sketch.

\section{BIBLIOGRAPHY}

Alvarez Díaz, F., de Rábago, G., Urquia, M., Castillón, L., de Vega N. G., Lozano, C., and Sánchez, P. A. (1965). Nueva valvula mitral artificial. Resultados experimentales. Rev. esp. Cardiol., 18,351 .

Davila, J. (1965). Symposium on Heart Substitutes, South Eastern Pennsylvania Heart Association, January, 1965.

Duvoisin, G. E., Brandenburg, R. O., and McGoon, D. C. (1967) Factors affecting thromboembolism associated with prosthetic
heart valves. Circulation, 35, Suppl. 1, p. 70. [Cited in Ellis, F. H. (1967).]

Edmunds, L. H., Wooler, G. H., and Watson, D. A. (1966). Clinical experience with the Alvarez and Starr-Edwards prosthetic mitral valves. J. thorac. cardiovasc. Surg., 51, 185.
Effler, D. B., and Groves, L. K. (1963). Mitral valve replacement: Clinical experience with the ball-valve prosthesis. Dis. Chest, जी 43, 529.

Ellis, F. H. (1967). Surgery for Acquired Mitral Valve Disease. Saunders, Philadelphia.

Herr, R. H., Peterson, C. R., Crisera R. V., Starr, A., and Griswold, H. E. (1966). Etiology of poor results following valve replacement surgery (Abstr.). Circulation, 34, Suppl. 3, p. 127.

Hughes, R. K. (1965). Complications of Starr-Edwards mitral valve replacement. J. thorac. cardiovasc. Surg., 49, 731.

Melrose, D. G., Bentall, H. H., McMillan, I. K. R., Flege, J. B., $\overrightarrow{0}$ Alvarez Diaz, F. R., Nahas, R. A., Fautley, R., and Carson, J. (1964). The evolution of a mitral-valve prosthesis. Lancet, 2. 623. $\vec{\omega}$

Starr, A., Herr, R. H., and Wood, J. A. (1966). The present status of $\mathcal{O}$ valve replacement. In VII Congr. int. cardiovasc. Soc., Philadefphia, Sept. 16-18, 1965. J. cardiovasc. Surg., 7, Suppl. 2, p. 95 experience. (1967). Mitral replacement. Review of six years' is thiovasc. Surg., 54, 333. 